\title{
Trade in mislabeled endangered sharks
}

The Conference of the Parties (CoP) of the Convention on International Trade in Endangered Species of Wild Fauna and Flora (CITES), the global treaty that regulates wildlife trade, will meet in Sri Lanka later this year (1). Among the species to be proposed for Appendix II listing, as in previous CoPs, are globally endangered pelagic sharks, this time the shortfin (Isurus oxyrinchus) and longfin (I. paucus) makos (2). However, because species such as sharks are often mislabeled $(3,4)$, the current CITES monitoring requirements (5) are not sufficient protection. In addition to listing these sharks on Appendix II, CITES signatory nations must invest in comprehensive genetic testing to ensure that listed species are not disguised as legally traded products.

There are currently 12 shark species listed on Appendix II (6), but evidence shows that the listing is not curtailing trade as designed. For example, the basking shark (Cetorhinus maximus) was targeted for centuries by fishers in the northeast Atlantic for its oil, meat, and high-value fins (7). In the second half of the 20th century, its abundance decreased by $90 \%$ in key aggregation sites in 25 years (half a generation) (8). As a result, the International Union for Conservation of Nature (IUCN) Red List classified it as Endangered in Europe (8). It was added to the CITES Appendix II in 2003 (6), and to the Convention on the Conservation of Migratory Species of Wild Animals (CMS) Appendix II in 2006 (7, 8). In 2007, thanks in part to these listings, the European Union (EU) prohibited fishing or landing the species (7, $8)$. However, there are still reports of illegal landings and sales of basking sharks (8). Data between 2003 and 2017 show 404 tons landed from the northeast Atlantic, where they remain endangered (9). Moreover, basking shark fins were confirmed in markets in Hong Kong, Japan, and the United States years after the CITES listing (3).

The basking shark is not an isolated case. Forensic genetic studies confirm fins in Hong Kong markets belonging to several other CITES Appendix II listed species, including scalloped (Sphyrna lewini) and great hammerhead (S. mokarran) sharks, even though populations remain globally endangered $(4,10)$. Furthermore, S. lewini fins have been genetically identified in UK wholesale markets among processed fins of other, non-endangered species (11).

Clearly, the CITES listing has not completely deterred the international trade of endangered sharks. To regulate mislabeled illegal products, all CITES signatory nations must allocate sufficient resources to coordinate species identification methodologies for fast, routine monitoring of shark products across borders [e.g., $(3,12)]$. Financial and knowledge resources will need to be made available to help some nations achieve this. Without these coordinated global actions, the future of endangered pelagic sharks remains precarious.

\section{David W. Sims ${ }^{1,2 *}$ and Matthew T. Frost ${ }^{1}$}

${ }^{1}$ Marine Biological Association of the UK, Plymouth PL1 2PB, UK. ${ }^{2}$ University of Southampton, Southampton SO14 3ZH, UK.

*Corresponding author. Email: dws@mba.ac.uk 


\section{REFERENCES AND NOTES}

1. CITES, Conference of the Parties (https://cites.org/eng/cop/index.php).

2. CITES, "Proposals for amendment of Appendices I and II" (https://cites.org/eng/cop/18/prop/index.php).

3. J. E. Magnusson et al., Anim. Conserv. 10, 199 (2007).

4. D. Cardenosa et al., Conserv. Lett. 11, e12457 (2017).

5. CITES, “The CITES Appendices” (www.cites.org/eng/app/index.php).

6. Convention on International Trade in Endangered Species of Wild Fauna and Flora, "History of CITES listing of sharks (Elasmobranchii)" (www.cites.org/eng/prog/shark/history.php).

7. D. W. Sims, Adv. Mar. Biol. 54, 171 (2008).

8. D. W. Sims et al., Cetorhinus maximus (The IUCN Red List of Threatened Species, 2015); www.iucnredlist.org/species/4292/48953216.

9. On the Food and Agriculture Organization of the United Nations Global Capture Production Fishery Statistics site (www.fao.org/fishery/statistics/global-captureproduction/query/en), under the "Fishing Area" tab, expand (+) "Marine," then "Atlantic Ocean and adjacent seas," then select "Atlantic, Northeast." Under the "Species" tab, expand "Marine fishes," then "sharks, rays \& chimaeras," then select "Basking shark." Under the "Time" tab, select years 2003 to 2017. Then click "submit." The annual landings displayed on screen (2003 to 2017) add up to 404 tons.

10. A.T. Fields et al., Conserv. Biol. 32, 376 (2017).

11. C. A. D. Hobbs et al., Sci. Rep. 9, 1028 (2019).

12. D. Cardenosa et al., Sci. Rep. 8, 16313 (2018). 